\title{
Exploration of Leuconostoc mesenteroides Sub sp mesenteroides from Indian Fermented Food for Curd Preparation
}

\author{
Trupti K. Vyas", Prachi Desai, Avantika R. Patel and K.G. Patel
}

Food Quality Testing Laboratory, N M College of Agriculture, Navsari Agricultural University, Navsari - 396450, Gujarat, India

*Corresponding author

\author{
A B S T R A C T
}

\begin{tabular}{|l|}
\hline K e y w or d s \\
Antimicrobial \\
activity, Curd, \\
LAB, Leuconostoc \\
mesenteroides, \\
Probiotic.
\end{tabular}

Keywords

\section{Introduction}

India is known for its traditional fermented foods like idali, dhosa, khaman, dhokal etc. These fermented foods contain LAB which is responsible for production of lactic acid in food. Due to fermentation it provides typical taste and has high health benefits.

These fermented foods contain lactic acid producing microbes. Generally, lactic acid bacteria are Gram-positive bacteria that do not form spores and which are able to grow both in the presence and absence of oxygen. Another common trait of lactic acid bacteria is their inability to manufacture the many compounds that they need to survive and grow.
LAB are also widely used at commercial level for production of fermented food products, such as yogurt (Streptococcus spp. and Lactobacillus spp.), cheeses (Lactococcus spp.), sauerkraut (Leuconostoc spp.), fermented milk (L.casei strain Shirota) and sausage. LAB are amongst the best studied microorganisms for human health advantageous effects and fermentation. Significant novel developments have been made in the research of lactic acid bacteria in the areas of multidrug resistance, bacteriocins, osmoregulation, autolysins and bacteriophages. Advancement has also been made in the production of food grade genetically modified LAB. They are also 
widely used as probiotics. Probiotics are live microorganisms which are defined by the World Health Organization/ Food and Agricultural Organization (2001) as: "Live microorganisms whose administration in adequate amount to the body is able to confer a health beneficial effect on the host". The most common types of microbes which are used as probiotics are lactic acid bacteria (LAB) and Bifidobacteria. Hence, present study aims to isolate $\mathrm{LAB}$ from fermented food and their application as probiotic in curd preparation.

\section{Materials and Methods}

\section{Isolation of bacterial strains and culture conditions}

For isolation of LAB, different batter samples of idali, khaman and handavo which are traditionally used in Indian home were used. For isolation of LAB, samples were serially diluted up to $10^{-7}$ in sterile distilled water and plated on De Man, Rogosa and Sharpe (MRS) agar plates (Yang et al., 2012). Plates were incubated at $37 \pm 2{ }^{\circ} \mathrm{C}$ for 2 - 4 days. Based on colony morphology, different bacteria were isolated in pure culture and stored on MRS slant at $4{ }^{\circ} \mathrm{C}$ until the use.

\section{Screening for lactic acid bacteria (LAB)}

\section{Plate assay}

To examine the lactic acid producing ability, cells were primarily screened on agar plate. For screening, an agar plate method was developed in laboratory in which MRS agar was supplemented with $\mathrm{CaCO}_{3}$. Isolate which produced higher lactic acid showed zone of clearance on agar plate. Thus it was easily identified based on clearance zone. Isolated pure cultures were streaked on these plates and plates were incubated at $37 \pm 2{ }^{\circ} \mathrm{C}$. Lactic acid producing bacteria showed zone of clearance on MRS were selected for further study.

\section{Quantification of lactic acid production}

Isolates which showed highest zone of clearance were selected for their lactic acid production efficacy. $1 \mathrm{ml}$ of $18 \mathrm{hrs}$ old inoculum was inoculated in MRS broth. After incubation, cells were removed by centrifugation and supernatant was used for lactic acid determination. The amount of lactic acid in fermentation broth was determined by transferring $10 \mathrm{ml}$ of supernatant into $100 \mathrm{ml}$ flask along with $1 \mathrm{ml}$ of phenolphthalein indicator $(0.5 \%$ in $5 \%$ alcohol). Sample was titrated with $0.25 \mathrm{M}$ $\mathrm{NaOH}$ for the appearance of pink color. The amount of $\mathrm{NaOH}$ used was calculated and corresponding lactic acid \% W/V was determined (Fortina et al., 1973).

\section{Identification of isolate}

\section{Morphological and biochemical characterization}

Isolate which produced higher lactic acid was identified by morphological and biochemical characterization according to Bergey's Manual of Systematic Bacteriology (De Vos et al., 2001). Identification was further confirmed by VITEC analyzer.

\section{Antimicrobial activity}

LAB are generally produced bacteriocin and other antimicrobial compounds. Their antimicrobial activity was examined against Escherichia coli, Micrococus lutues ATCC 10240, Serratia marcescens ATCC 14756, Yersinia enterocolitica ATCC 23715, Staphylococcus aureus ATCC 11632, Listeria monocytogenes(4b) ATCC 13932, Bacillus cereus ATCC 11778, Proteus vulgaris ATCC 33420, Salmonella poona ATCC 4840, 
Enterococcus faecalis ATCC 14506. Antimicrobial activity was examined by well diffusion assay (Schillinger U, Lucke FK (1987). 18 hrs old culture of test pathogen was streaked on Muller Hinton agar. Wells were prepared in agar plate with sterile cup borer and supernatant of potential lactic acid producing isolate was place in well. Plates were incubated at $37^{\circ} \mathrm{C}$ for $24 \mathrm{hrs}$. Zone of inhibition was measured in $\mathrm{mm}$. The antimicrobial activity was determined by measuring the zone of inhibition around the well.

\section{Determination of antibiotic resistance of the isolates}

To evaluate the antibiotic susceptibility, disc diffusion method of Kirby-Bauer assay (Bauer et al., 1959) was performed. Octodiscs (Combi 61, G-I-minus, Combi 506) (HiMedia Laboratory Pvt Ltd, India) were used for the assay of antibiotic sensitivity. Octodisc was placed on agar plate spread with tested organism. The plates were incubated at $37{ }^{\circ} \mathrm{C}$ for 24 hours. The resistances were determined according to the zone of inhibition.

\section{Application in curd preparation}

To evaluate the efficacy of LAB bacteria as probiotics, culture was used for curd preparation. $18 \mathrm{hrs}$ old culture broth was used as inoculum. Cells from the broth were harvested by centrifugation and washed twice with distilled water. $1 \%$ inoculums was used for the study. Four different treatment were used for this experiment viz. T1= Milk + starter culture (control), $\mathrm{T} 2=$ Leuconostoc mesenteroides + Milk (closed system), T3 = Leuconostoc mesenteroides + Milk (open system) and T4 = Leuconostoc mesenteroides + Milk+ Starter culture. Milk sample after inoculation of bacterial culture incubated overnight.
Next day samples were analyzed for total carbohydrate, protein, fat and moisture content.

\section{Results and Discussion}

LAB are among the most important groups of microorganisms used in fermented food. They provide a typical taste and quality to fermented foods. They are widely use for preservation as they produce lactic acid which lowers the $\mathrm{pH}$ and thus beneficial in the preservation of food. The lowered $\mathrm{pH}$ inhibits the growth of most other food spoilage microorganisms. Along with lactic acid they are also able to produce growth inhibiting substances. For isolation of LAB, batter (idali, khaman and handavo) was collected from different home and local market.

MRS agar was used for the isolation of LAB and cells grown on agar were selected. Total 25 isolates based on their colony characters were selected and purified. Isolated samples were stored on MRS at $4{ }^{\circ} \mathrm{C}$ until the use. Isolates were designated as L1 to L25.

All isolates were morphologically characterized by Gram's staining. Data suggests that all isolates were Gram positive and have irregular coccoid to oval morphology. All produce metachormatic granules during their growth. These isolates were primarily screened by growing them on MRS agar contain calcium carbonate. Organic acid producing isolates lowers the $\mathrm{pH}$ and thus solubilizer calcium carbonate making clear zone around colony (Fig. 1). Eleven isolates which showed higher clearance zone on MRS were selected for further studies. All these 11 isolates were screened for their quantitative lactic acid production. Lactic acid production was measured by titration. Highest lactic acid was produced by L11 (443 ppm) and least was by L2 (102 ppm). Thus potential isolate L11 was used for further 
studies and identified by biochemical test. L11 was identified as described in Bergey's Manual of Systematic Bacteriology. Oxidase and catalase tests were negative. L11 is able to ferment glucose, lactose, sucrose, xylose, mannose and maltose sugar. Cells showed positive esculin test. Based on the morphological and biochemical tests, L11 was identified as Leuconostoc mesenteroides.

Identification was further confirmed by sending culture for identification by VITEK analyzer (Advance Diagnostic Lab, Surat). L11 was confirmed as Leuconostoc mesenteroides subsp. mesenteroides.

LAB are generally slow grower and required complex media to grow. To observe growth pattern, cells were grown in MRS broth and optical density was monitored at $600 \mathrm{~nm}$ upto 120 hrs. Growth starts from $24 \mathrm{hrs}$ and reached its maximum up to $96 \mathrm{hrs}$ and their after declined (Fig. 2). Antimicrobial activity of the isolate was examined against some pathogenic microbes. It inhibits growth of Escherichia coli, Micrococus lutues ATCC 10240, Serratia marcescens ATCC 14756, Staphylococcus aureus ATCC 11632 and Listeria monocytogenes ATCC 13932 (Table 1). However, it does not inhibit the growth of Yersinia enterocolitica ATCC 23715, Proteus vulgaris ATCC 33420, Salmonella poona ATCC 4840, Enterococcus faecalis ATCC 1450.

Isolate was tested for their antimicrobial resistant against different antibiotics using octadisc. Cells were sensitive to all tested antibiotic viz. Imipenem, Meropenem, Ciprofloxacin, Tobramycin, Moxifloxacin, Ofloxacin, Sparfloxacin, Levofloxacin, Ciprofloxacin, Ofloxacin, Sparfloxacin, Gatifloxacin, Teicoplanin, Azithromycin, Vancomycin, DoxcyclineHcl, Ampicillin, Ciprofloxacin, Colistin, Co-Trimoxazole, Gentamicin, Nitrofurantoin, Streptomycin, Tetracycline (Table 2).

Fig.1 Growth of Leuconostoc mesenteroides sub sp. mesenteroides on MRS agar

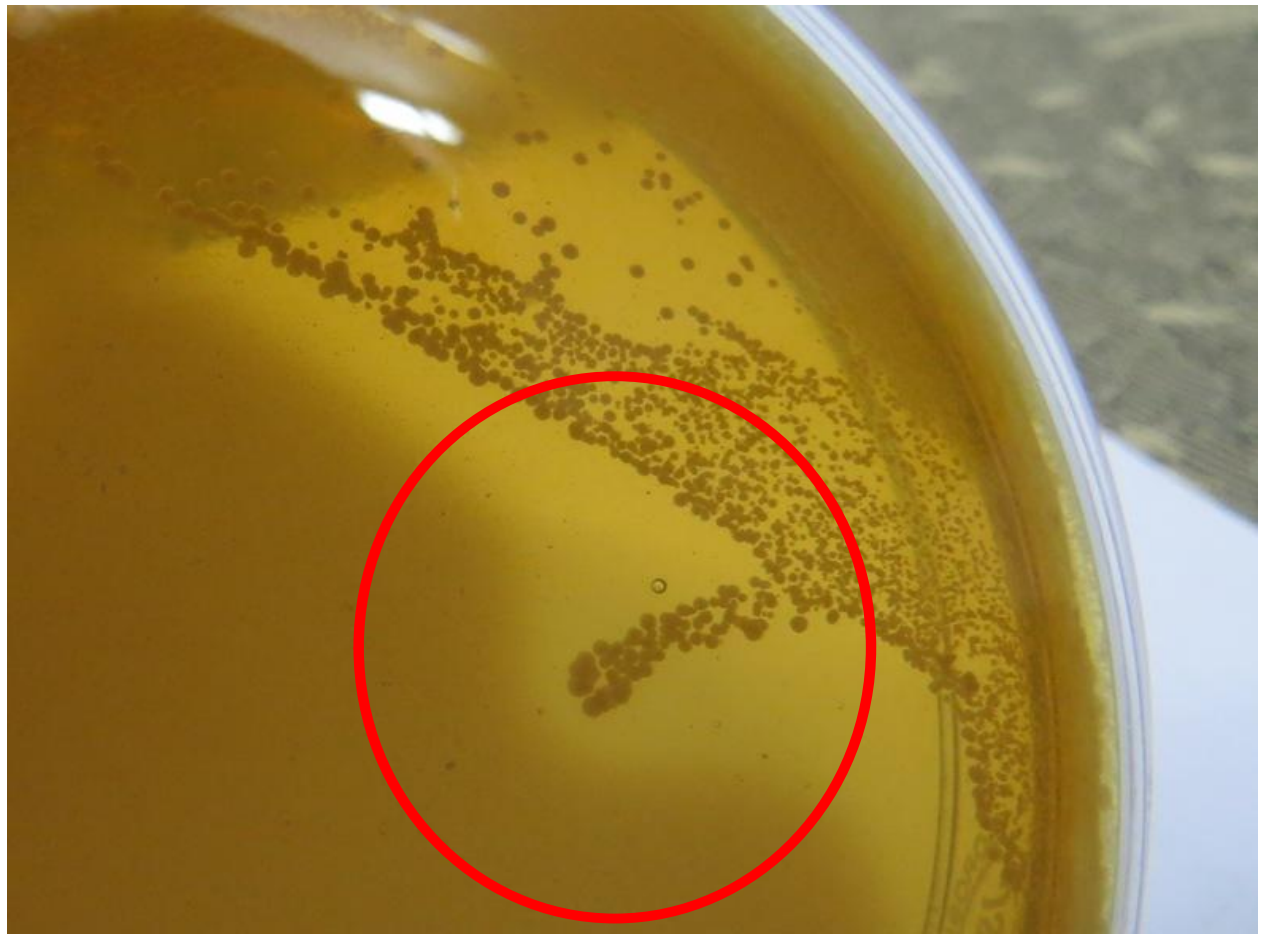


Fig.2 Growth pattern of Leuconostoc mesenteroides subsp. mesenteroides

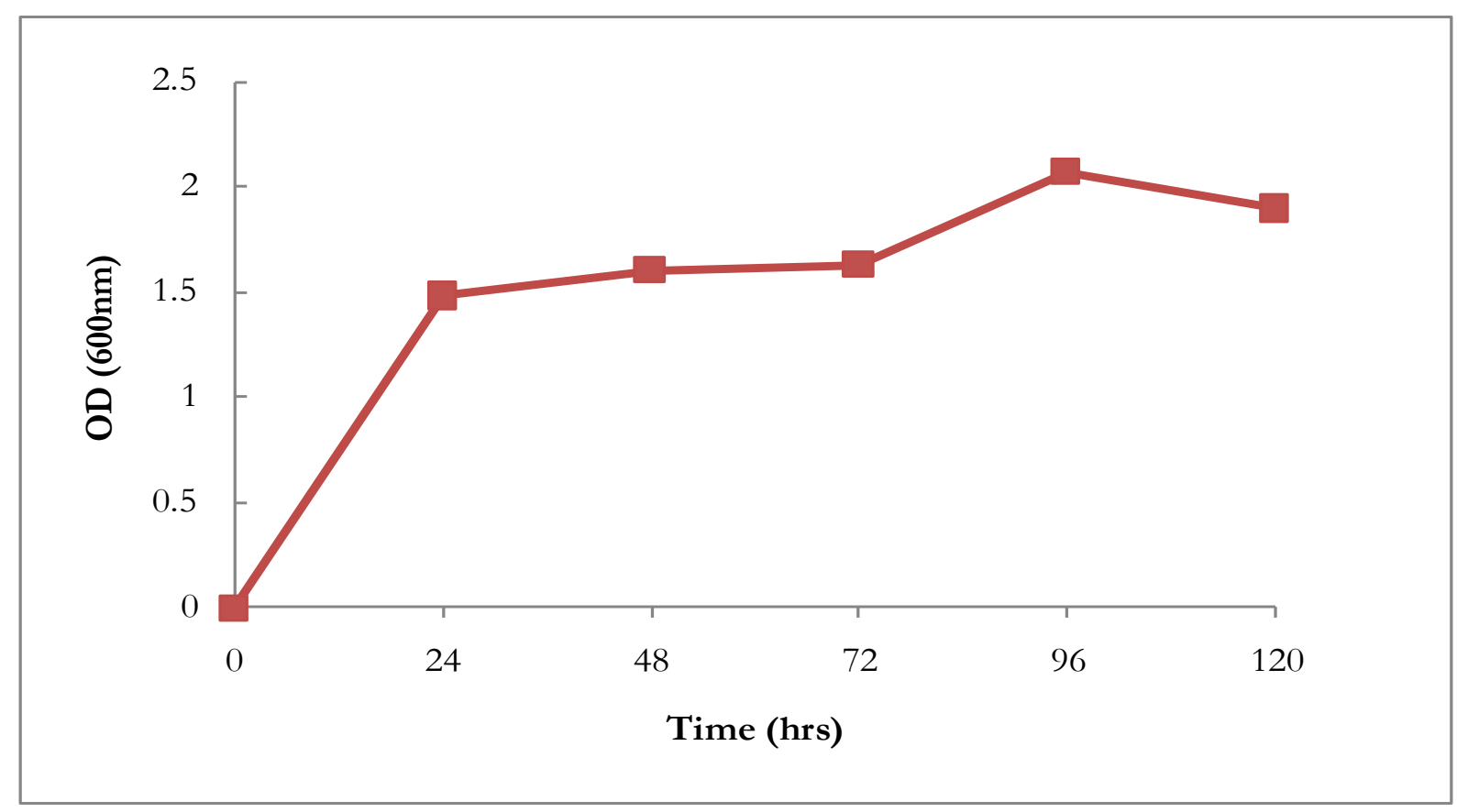

Table.1 Antimicrobial activity of Leuconostoc mesenteroides subsp. Mesenteroides against test microbes

\begin{tabular}{|l|c|}
\hline \multicolumn{1}{|c|}{ Pathogen } & Inhibition Zone (mm) \\
\hline Escherichia coli & 12 \\
\hline Micrococcus lutues & 14 \\
\hline Serratia marcescens & 15 \\
\hline Yersinia enterocolitica & $\mathrm{Ab}$ \\
\hline Staphylococcus aureus & 19 \\
\hline Listeria monocytogenes & 12 \\
\hline Bacillus cereus & $\mathrm{Ab}$ \\
\hline Proteus vulgaris & $\mathrm{Ab}$ \\
\hline Salmonella poona & $\mathrm{Ab}$ \\
\hline Enterococcus faecalis & $\mathrm{Ab}$ \\
\hline
\end{tabular}


Table.2 Antibiotic sensitivity assay of Leuconostoc mesenteroides sub sp. Mesenteroides

\begin{tabular}{|l|c|c|}
\hline Antibiotics & Concentration $(\boldsymbol{\mu g})$ & Senstive / Resistance \\
\hline Imipenem & 10 & $\mathrm{~S}$ \\
\hline Meropenem & 10 & $\mathrm{~S}$ \\
\hline Ciprofloxacin & 5 & $\mathrm{~S}$ \\
\hline Tobramycin & 10 & $\mathrm{~S}$ \\
\hline Moxifloxacin & 5 & $\mathrm{~S}$ \\
\hline Ofloxacin & 5 & $\mathrm{~S}$ \\
\hline Sparfloxacin & 5 & $\mathrm{~S}$ \\
\hline Levofloxacin & 5 & $\mathrm{~S}$ \\
\hline Ciprofloxacin & 5 & $\mathrm{~S}$ \\
\hline Ofloxacin & 5 & $\mathrm{~S}$ \\
\hline Sparfloxacin & 5 & $\mathrm{~S}$ \\
\hline Gatifloxacin & 5 & $\mathrm{~S}$ \\
\hline Teicoplanin & 30 & $\mathrm{~S}$ \\
\hline Azithromycin & 15 & $\mathrm{~S}$ \\
\hline Vancomycin & 30 & $\mathrm{~S}$ \\
\hline DoxcyclineHcl & 30 & $\mathrm{~S}$ \\
\hline Ampicillin & 10 & $\mathrm{~S}$ \\
\hline Ciprofloxacin & 10 & $\mathrm{~S}$ \\
\hline Colistin & 10 & $\mathrm{~S}$ \\
\hline Co-Trimoxazole & 25 & $\mathrm{~S}$ \\
\hline Gentamicin & 10 & $\mathrm{~S}$ \\
\hline Nitrofurantoin & 300 & $\mathrm{~S}$ \\
\hline Streptomycin & 10 & $\mathrm{~S}$ \\
\hline Tetracycline & 30 & \\
\hline
\end{tabular}

The traditional fermented dairy products can be possibly a good source of potential probiotic organisms. Here curd prepared using Leuconostoc mesenteroides showed good organolaptic properties. Leuconostoc mesenteroides containing curd has thick consistency and flavor compared to control. Moisture content was almost similar in al treatment ranging from 88.7 to $89 \%$. Carbohydrate content was higher in T4 followed by T3 and T2. T1 contain lowest carbohydrate content. Protein content was higher in T1 (3.25\%) followed by T2 (3.14 $\%)$ and T3 $(2.95 \%)$ and least content was in $\mathrm{T} 4$ (2.07). Fat content was maximum in T4
(1.7 $\mathrm{g} \%)$ followed by T3 (1.5\%) and T1 with same content of $1.5 \mathrm{~g} \%$. Least $0.9 \mathrm{~g} \%$ was found in $\mathrm{T} 2$ treatment.

The term Lactic Acid Bacteria is conventionally reserved for genera in the order Lactobacillales, which includes Lactobacillus, Leuconostoc, Pediococcus, Lactococcus and Streptococcus, in addition to Carnobacterium, Enterococcus, Oenococcus, Tetragenococcus, Vagococcus, and Weisella. Lactic acid bacteria (LAB) are generally recognized as safe (GRAS), a cluster of related bacteria that ferment carbohydrates and produce lactic acid (Ashe and Paul, 
2010). Lactic acid fermentation of cerealbased foods is a traditional technology used by Indian. It is widely used for preparation of idali, dhosa, dhokla, handvo etc. in India.

Chopra and Mehra (2015) have isolated two strain of $L$. plantarum and two strain $L$. fermentum from dosa and idli batter. These isolates produce bacteriocins which have molecular weights between $16-48 \mathrm{KD}$.

Lactic acid bacteria produce antibacterial compounds that are known as bacteriocins. Bacteriocins act by punching holes through the membrane that surrounds the bacteria. Thus, bacteriocins activity is usually lethal to the bacteria. Examples of bacteriocins are nisin and leucocin. Nisin inhibits the growth of most gram-positive bacteria, particularly spore-formers (e.g., Clostridium botulinum. This bacteriocin has been approved for use as a food preservative in the United States since 1989. Leucocin is inhibitory to the growth of Listeria monocytogenes.

Leuconostoc mesenteroides is the most commonly encountered bacterium not only in Indian fermented food (Nout and Sarkar 1999; Kumar et al., 2012; Mukherjee et al., 1965) but also found in various countries of world (Lee, 1994; Lee et al., 1983; Orillo and Pederson, 1968; Souane et al., 1987). LAB contributes lactic acid and acetoin, imparting sour taste and a pleasant flavour (Aidoo et al., 2006). As per FAO report, Leuconostoc mesenteroides subsp. mesenteroides serves as the main flavouring agent in cultured milk. It produces diacetyl, acetic acid, acetaldehyde and other flavour compounds but less carbon dioxide.

Leuconostoc mesenteroides subsp. Mesenteroides is able to inhibit the growth of Listeria monocytogenes ATCC 13932. Bellil et al., (2014) has also reported inhibition of Listeria innocua ATCC 33090 by
Leuconostoc mesenteroides. Leuconostoc mesenteroides subsp. mesenteroides used for curd preparation shows that it lowers the carbohydrate and fat content and have high protein content.

Out of all LAB isolated from different fermented food, isolate L11 showed higher lactic acid production. Morphological and biochemical characterization revealed that it is Leuconostoc mesenteroides subsp. mesenteroides. It inhibits the growth of potential food borne pathogen Listeria monocytogenes. It lowers the carbohydrate and fat content of curd and also provides thick consistency and flavor to curd. Thus it can be used as probiotic for curd preparation.

\section{References}

Aidoo, K. E., Nout, N.J.R., Sarkar, P.K 2006. Occurrence and function of yeasts in Asian indigenous fermented foods. FEMS Yeast Res. 6(1), 30-39.

Ashe, B., Paul, S., 2010. Isolation and characterization of lactic acid bacteria from dairy effluents. J. Env. Res. Dev. 4, 983.

Bauer, A. W., Perry, D. M., Kirby. W.M.M., 1956. Single disc antibiotic sensitivity testing of Staphylococci. AMA Arch. Inter. Med. 104, 208 - 216.

Bellil, Y., Benmechernene, Z., Chahrour, W., Naoui, N., Kihal, M., 2014. Selection and evaluation of anti-listerial activity of Leuconostoc mesenteroides wild strains isolated from Algerian raw dromedary milk. J. Food Process. Technol. 2014, 5:12

Chopra, S., Mehra, S., 2015. Identification of lactic acid bacteria from fermented Indian food and study its physical and cultural parameters on bacteriocins produced by them. International J. Res. Appl. Sci. Eng. Technol. 3, 339 - 343.

De Vos, P., Garrity, G., Jones, D., Krieg, 
N.R., Ludwig, W., Rainey, F.A., Schleifer, K.H., Whitman, W.B., 2009. Bergey's Manual of Systematic Bacteriology. Second edition, vol. 3, Springer

FAO/WHO. 2001. Food and Agriculture Organization of the United Nations/ World Health Organization

Fortina, M.G., Parini, C., Rossi, P.R., Magnhim, P.H., 1973. Mapping of three plasmids from Lactobacillus helveticus ATCC 15009. Lett. in App. Microbial. $17,303-306$.

http://www.fao.org/ag/againfo/resources/docu ments/MPGuide/mpguide4.htm

Kishore, G., Armugam, K., Gopal, S.V., Averineni, R.K., Bhat, M., Udupa, N., 2013. Development of RP-HPLC method for simultaneous estimation of lactic acid. And glycolic acid Der. Pharma Chemica, 5(4), 335 - 340.

Kumar, S.R., Kanmani, P., Yuvaraj, N., Paari, K.A., Pattukumar, V., ARUL, V., 2012. Traditional Indian fermented foods: a rich source of lactic acid bacteria. Int. J. Food Sci. Nutrit. 64, 1-14.

Lee, C.H., 1994. Importance of lactic acid bacteria in non-dairy food fermentation. In: Lee, C.H., Adler-Nissen, J. and Barwald, G. (Eds.) Lactic Acid Fermentation of Non-dairy Food and Beverages. HarnLimWon.

Lee, C.H., Cho, T.S., Lim, M.H., Kang, J.h., Yang, H.C., 1983. Studies on the Sikhae fermentation made by flat-fish.
Korean J. Appl. Microbiol. Bioeng. 11, 53-58.

Mukjerjee, S.K., Albury, M.N., Pederson, C.S., Vanveen, A.G., Steinkraus, K.H., 1965. Role of Leuconostoc mesenteroides in leavening the batter of idali, a fermented food. Appl. Microbiol. 13, 227 - 231.

Nout, M.J.R., Sarkar, P.K., 1999. Lactic acid food fermentation in tropical climates. Antonie van Leeuwenhoek 76, 395 401.

Olaoye, O.A., Onilude, A.A., 2011. Quantitative estimation of antimicrobials produced by lactic acid bacteria isolated from Nigerian beef. Int. Food Res. J. 18(3), 1155 - 1161.

Orillo, C.A., Pederson, C.S., 1968. Lactic acid bacterial fermentation of Burong dalag. Appl. Microbiol. 16, 1669 - 1671.

Schillinger, U., Lucke, F.K., 1987. Identification of Lactobacilli from meat and meat products. Food Microbiol. 4, $1990-208$.

Souane, M., Kim, Y.B., Lee, C.H., 1987. Microbial characterization of Gajami-sikhae fermentation. Korean J. Appl. Microbial. Bioeng. 15, 150 157.

Yang, E., Fan, L., Jiang, Y., Doucette, C., Fillmore, S., 2012. Antimicrobial activity of bacteriocin-producing lactic acid bacteria isolated from cheeses and yogurts. ABM Express. 2, 48.

\section{How to cite this article:}

Trupti K. Vyas, Prachi Desai, Avantika R. Patel and Patel, K.G. 2017. Exploration of Leuconostoc mesenteroides Sub sp mesenteroides from Indian Fermented Food for Curd Preparation. Int.J.Curr.Microbiol.App.Sci. 6(10): 3137-3144.

doi: https://doi.org/10.20546/ijcmas.2017.610.368 